УДК 658.7

\title{
НЕОБХІДНІСТЬ ЗАСТОСУВАННЯ ІННОВАЦІЙНИХ ЛОГІСТИЧНИХ ПРОЦЕСІВ ДЛЯ РОЗВИТКУ СУЧАСНИХ ПІДПРИЕМСТВ
}

\section{THE NESSESITY OF APPLICATION OF INNOVATIVE LOGISTICS PROCESSES FOR THE DEVELOPMENT OF MODERN ENTERPRISES}

\author{
Гук Ольга Володимирівна \\ кандидат економічних наук, \\ Національний технічний університет України \\ «Київський політехнічний інститут імені Ігоря Сікорського» \\ ORCID: https://orcid.org/0000-0002-8129-8392 \\ Кучма Олена Юріївна \\ студентка, \\ Національний технічний університет України \\ «Київський політехнічний інститут імені Ігоря Сікорського» \\ ORCID: https://orcid.org/0000-0001-5040-9232 \\ Мельник Анна Володимирівна \\ студентка, \\ Національний технічний університет України \\ «Київський політехнічний інститут імені Ігоря Сікорського» \\ ORCID: https://orcid.org/0000-0002-8658-8751
}

\author{
Guk Olga, Kuchma Olena, Melnyk Anna \\ National Technical University of Ukraine \\ «lgor Sikorsky Kiev Polytechnic Institute»
}

\begin{abstract}
Стаття присвячена актуальним питанням застосування інноваційних логістичних процесів для розвитку вітчизняних підприємств. У статті розкрито роль інноваційних логістичних процесів як фрактору нарощення ефрективності діяльності в контексті інноваційної діяльності. Авторами проаналізовано як розвивалася електронна комерція в період пандемії. Визначено, що обмежувальні заходи негативно вплинули на транспорту логістику. У статті досліджено взаємозв'язок інноваційного розвитку та логістики. Авторами наведено динаміку комерційних рейсів територією ЄС за 2020 рік. У статі досліджено використання повного комплексу логістичних операцій (фрулфілмент). Виокремлено проблеми, які виникли перед підприємствами в контексті складської логістики. Розглянуто, яким чином змінилися підходи до методів управління логістикою на підприємствах. Наведено тенденції використання компаніями програмного забезпечення для роботи 3 ланцюгами поставок та нові можливості зробити логістичні ланцюги прозорими та швидко реагувати на зміни на всіх етапах логістичних процесів. Досліджено використання роботизації складських процесів, що впливає на активний розвиток підприємства та можливість використання цифрових двійників у логістиці. Проаналізовано рейтинг вартості складських приміщень у світі. Досліджено логістичні послуги ТОВ «Сільпо-ФУД», що є частиною однієї з найбільших рітейл груп країни Fozzy Group. Визначено необхідність оптимізації логістичних процесів для забезпечення гнучкості у діяльності підприємств в умовах COVID-19. Авторами запропоновано використання компаніями нових інноваційних логістичних підходів з метою розвитку сучасних підприємств. Окреслено необхідність формування інноваційних рішень, що сприятимуть ефективному використанню інноваційних логістичних процесів та оптимізації логістичної діяльності.
\end{abstract}

Ключові слова: логістична діяльність, інноваційні логістичні процеси, розвиток сучасних підприємств.

Статья посвящена актуальным вопросам применения инновационных логистических процессов для развития отечественных предприятий. В статье раскрыта роль инновационных логистических процессов как фрактора наращивания эффрективности деятельности в контексте инновационной деятельности. Авторами проанализи- 
ровано как развивалась электронная коммерция в период пандемии. Определено, что ограничительные меры негативно повлияли на транспортную логистику. В статье исследована взаимосвязь инновационного развития и логистики. Авторами приведена динамика коммерческих рейсов территории ЕС 2020 года. В статье исследовано использование полного комплекса логистических операций (фулфилмент). Выделены проблемы, которые возникли перед предприятиями в контексте складской логистики. Рассмотрено, каким образом изменились подходы к методам управления логистикой на предприятиях. Представлены тенденции использования компаниями программного обеспечения для работы с цепями поставок и новые возможности сделать логистические цепи прозрачными и быстро реагировать на изменения на всех этапах логистических процессов. Исследовано использование роботизации складских процессов, влияющих на активное развитие предприятия и возможность использования цифровых двойников в логистике. Проанализированы рейтинг стоимости складских помещений в мире. Исследовано логистические услуги ООО «Сильпо-ФУД», что является частью одной из крупнейших ритейл групп страны Fozzy Group. Определена необходимость оптимизации логистических процессов для обеспечения гибкости в деятельности предприятий в условиях COVID-19. Авторами предложено использование компаниями новых инновационных логистических подходов с целью развития современных предприятий. Определены необходимость фрормирования инновационных решений, способствующих эффективному использованию инновационных логистических процессов и оптимизации логистической деятельности.

Ключевые слова: логистическая деятельность, инновационные логистические процессы, развитие современных предприятий.

The article is devoted to topical issues of application of innovative logistics processes for the development of domestic enterprises. The article reveals the role of innovative logistics processes as a factor in increasing the efficiency of activities in the context of innovation. The authors analyze how e-commerce developed during the pandemic. It is determined that restrictive measures have negatively affected transport logistics. The article examines the relationship between innovation development and logistics. The authors present the dynamics of commercial flights through the EU in 2020. The article investigates the use of a full range of logistics operations (fulfilment). The problems that arose before the enterprises in the context of warehouse logistics are singled out. It is considered how the approaches to methods of logistics management at the enterprises have changed. Trends in the use of software to work with supply chains and new opportunities to make logistics chains transparent and responsive to changes at all stages of logistics processes are presented. The use of robotics of warehousing processes, which affects the active development of the enterprise and the possibility of using digital duplicates in logistics, is studied. The rating of the cost of warehouses in the world is analyzed. The logistics services of Silpo-FOOD LLC, which is part of one of the largest retail groups in the country Fozzy Group, have been studied. The necessity of optimization of logistic processes for providing flexibility in activity of the enterprises in the conditions of COVID-19 is defined. The authors propose the use of new innovative logistics approaches by companies in order to develop modern enterprises. The need for the formation of innovative solutions that will promote the effective use of innovative logistics processes and optimization of logistics activities is outlined.

Keywords: logistic activity, innovative logistic processes, development of modern enterprises.

Постановка проблеми. Сучасні реалії діяльності світової економіки диктують нові вимоги для стабільності діяльності та розвитку підприємств. Формування ефрективних логістичних процесів $€$ драйвером розвитку вітчизняних підприємств, а в умовах швидкозмінного середовища надзвичайно важливим завданням $€$ фрормування та оптимізація логістичної системи на підприємствах, що в свою чергу сприятиме економічному розвитку країни загалом в період пандемії. Для есрективного фрункціонування підприємств та нарощення конкурентних переваг на ринку, необхідними $є$ безперервні організаційно-технічні зміни, в тому числі в напрямку застосування інноваційних логістичних процесів, що зумовлює актуальність цієї статті.

Аналіз останніх досліджень і публікацій. Теоретичні та практичні засади логістичної та іноваційної діяльності розглядали у своїх працях наступні науковці: D. Brown, L. Graham, J. Tollier [6], Л. О. Кустріч [8].
Виділення невирішених раніше частин загальної проблеми. Незважаючи на значні дослідження науковців у логістичній галузі недостатньо дослідженими залишаються питання застосування інноваційних логістичних процесів з метою розвитку сучасних підприємств.

Формулювання цілей статті (постановка завдання). Метою статті $€$ дослідження необхідності застосування інноваційних логістичних операцій як фрактору розвитку сучасних підприємств. Основними цілями статті $€$ : виявлення головних недоліків логістичних систем; аналіз тенденцій використання компаніями програмного забезпечення для роботи 3 ланцюгами поставок; дослідження рейтингу вартості складських приміщень у світі; аналіз логістичних операцій на прикладі ТОВ «Сільпо-ФУД»;дослідити тенденції надання логістичних послуг в період пандемії; доведення необхідності використання інноваційних логістичних процесів на сучасних підприємствах. 
Виклад основного матеріалу дослідження. Динамічність зростання глобалізації діяльності підприємств сприяє підвищенню ролі логістики, як фрактору нарощення ефективності діяльності. Одними з найбільш важливих статей витрат, від яких залежать фрінансові результати діяльності сучасних підприємств, є статті, що пов'язані із логістикою. Крім того, стрімке збільшення кількості населення та посилення економічної експансії зумовлюють нарощення споживчого попиту, що у свою чергу призводить до прискорення переходу на електронну комерцію. На початкових етапах впровадження електронної комерції, особлива увага приділялась централізованим локаціям, що могли поєднувати запаси та збалансовані терміни доставки по широкій географрії, однак таке розташування логістичних об'єктів призводило до тривалих термінів доставки та її високої ціни. Згодом логістичні центри почали зміщувати ближче до кінцевих споживачів, що дозволило вирішити проблеми термінів та ціни доставки. Сьогодні, головними викликами є: забезпечення найкоротших термінів доставки та управління збільшенням обсягів повернення продукції.

В 2020 році, усі комерційні підприємства зазнали значного «шоку», початок пандемії був з викликом для всіх комерційних підприємств. Пандемія внесла значні корективи в темпи розвитку електронної комерції, зокрема були введені обмежувальні заходи, заборона подорожей та закриття роздрібної торгівлі у всьому світі. Все це вцілому спричинило стрімкий попит споживачів на покупки в інтернеті, а електронна комерція досягла історичного максимуму. При цьому, товари що мали найбільш низький попит в інтернет торгівлі, з введенням карантинних заходів стали найбільш затребуваними. Крім того, основними вимогами споживачів, стала оперативність, зручність та швидкість.

3 впровадженням карантину, обсяги електронної торгівлі становили 16,4\% від загальних роздрібних продажів, при цьому найбільш стрімко це зростання відбулось у Центральній та Східній Європі (21\%). Варто зазначити, що глобальне опитування показало, що 84\% споживачів, під час пандемії здійснювали онлайн покупки, зокрема використовувати інтернет для покупок почали не лише покоління Z і мілленіали, до них також долучились люди старших поколінь. Вважають, що за тенденцією зростання електронної торгівлі, такий відсоток приросту очікувався через декілька років, однак під впливом карантину, це відбулося за 3 місяці. Крім того, на зростання онлайн кон- куренції впливає зростання транскордонних продажів. 3 початком карантину, протягом першої половини 2020 року відбулось зростання транскордонної торгівлі на 21\%, а встановлення додатків, що дозволяють перекладати текст на 3309\% [4].

В той же час, підприємствам для того, щоб втримати свої ринкові позиції та забезпечити подальшу конкурентоспроможність на ринку необхідно було адаптувати не лише збутову політику, орієнтуючись на електронну комерцію. Для забезпечення безперервного виробництва та постачання продукції варто також пристосуватись до поточних умов шляхом технологічного розвитку. Це в свою чергу дозволить компаніям забезпечити свій інноваційний розвиток та бути на крок попереду конкурентів [3].

Взаємозв'язок інноваційного розвитку та логістики проявляється у наступних аспектах: застосовування логістики націлене на забезпечення підвищення ефективності від реалізації інноваційних проектів; з іншого боку, логістична система потребує інноваційного розвитку, для підвищення конкурентоспроможності і стабільності подальшого розвитку підприємств [8].

При цьому, обмежувальні заходи спричинили ускладнення у роботі транспортної логістики, відміна рейсових літаків, якими здійснюють поставки товарів, що в свою чергу зумовило зниження кількості авіаційних перевезень та зростання їх ціни [1].

Розглянемо динаміку комерційних рейсів територією ЄС за 2020 рік, (рис. 1).

Для забезпечення ефрективної доставки торгівлі та її оптимізації, все більшої популярності набуло використання повного комплексу логістичних операцій (фрулорілмент). Фулфрілмент - повний комплекс логістичних операцій від моменту оформлення покупцем замовлення до моменту отримання покупки. Перша половина 2020 року характеризується світовим зростанням логістичних компаній, що надають повний цикл логістичних послуг на 51\%. Використання такого типу логістичних послуг дозволяє компаніям боротись зі зростанням витрат та задовольняти очікування споживачів.

Крім того, все більш помітним $є$ перетворення транспортних платфрорм, що забезпечують лише перевезення до логістичних платформ. Зазначена тенденція сприяє створенню інновацій та цінового тиску на створення транспортних провайдерів, при тому, що в свою чергу позитивно впливає на споживачів. В середньому підприємства передають стороннім організаціям $16 \%$ із завдань ланцюга поставок, при цьому значення зазначе- 


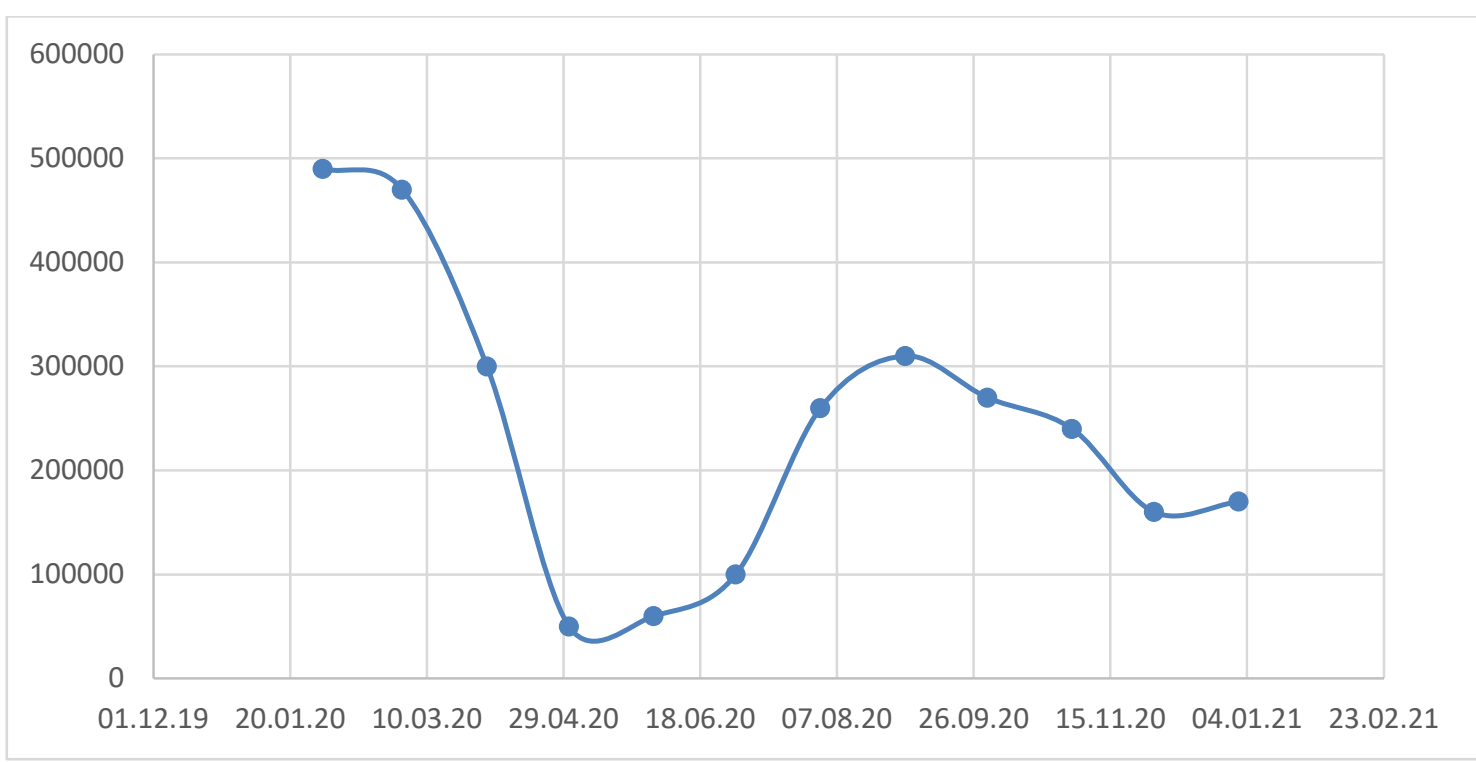

Рис. 1. Динаміка кількості комерційних рейсів $€ \subset, 2020$ рік Джерело: [7]

ного показника у компаній, дохід яких перевищує 199 млн доларів, становить 37\% [2].

Якщо ж аналізувати компанії, що мають достатньо ресурсів для реалізації власної логістики, але не оптимізують процеси, тоді це означає, що перед ними виникли певні проблеми. Початок пандемії спричинив навантаження на сегмент складської логістики, розподільчі центри стали переповненими, а споживчий попит - важкопрогнозованим. Через декілька місяців, більшість компаній вирішили питання 3 переповненістю складів, однак питання нестабільності попиту залишилось відкритим. Крім того, останніми роками серед рітейлерів набув популярності метод управління запасами Just-in-Time, в основі якого лежить мінімізація запасів та зниження витрат на зберігання. Налагоджена робота даного методу, дозволяла компаніям виробникам мінімізувати залишки продукції, які виникали внаслідок неправильного прогнозування збуту, а для компаній рітейлерів, швидко адаптуватись до змінного попиту. Однак, пандемія внесла значні корективи у чітко налагоджені ланцюги поставок, встановленні обмеження унеможливили швидку доставку необхідної кількості товарів, а відсутність запасів не дозволила продовжувати роботу підприємствам.

Зважаючи на викликані пандемією обмеження, компанії переглянули підхід до методів управління логістикою і почали перехід від моделі Just-in-Time до моделі Just-in-Case, ще передбачає утримання певних страхових запасів продукції і оптимізацію логістичних процесів. Дане рішення дозволить компаніям бути більш гнучкими за умов можливих дефіцитів продукції, однак збільшить складські витрати та спричинить ризик затримки товарів на складах. При цьому, якщо аналізувати використання компаніями програмного забезпечення для роботи 3 ланцюгами поставок, спостерігається наступна тенденція:

- TMS-системи управління транспортом. 2019 рік - 92\% компаній, 2021 - 72\% компаній;

- WMS-система управління складом. 2019 рік - 87\% компаній, 2021 рік - 75\% компаній;

- Система управління автопарком. 2019 рік90\% компаній, 2020 рік - 71\% компаній.

Загалом тенденція 2019 року сприяла поширенню використання платформ управління ланцюгами, однак пандемія призвела до зростання втручання людини в процес роботи ланцюгів, тим самим знизила їх ефективність. Окрім того, 2020 рік характеризується активним впровадженням інноваційних процесів у логістичні ланцюги, так логістичні компанії все більше почали застосовувати управління логістичними ланцюгами в онлайн режимі. Bce це в сукупності надало компаніям нові можливості зробити логістичні ланцюги прозорими та швидше реагувати на зміни на всіх етапах логістичних процесів [9].

Зростання попиту на логістичні об'єкти, що знаходяться найближче до споживачів призводить до зростання вартості складських приміщень протягом останніх років. Розглянемо вартість складських приміщень у світі (табл. 1). 
Отже, ми можемо спостерігати, що у період пандемії 2020 року не відбулось значного падіння цін на оренду складських приміщень, хоча і відбувся значний «бум» на ринку логістичних послуг. Активний розвиток також спостерігається у роботизації складських процесів, що забезпечують створення інноваційних процесів на складі, які характеризуються більшою надійністю, керованістю та меншою кількістю помилок. Окрім роботизації складських процесів, яскравим прикладом використання інноваційних процесів $€$ впровадження цифрових двійників для роботи 3 різними об'єктами. Використання цифррових двійників у логістиці робить можливим створення точних моделей розподільчих центрів, завдяки чому власники цих технологій зможуть віртуально тестувати різні сценарії роботи, аналізувати їх та обирати оптимальний без ризиків негативного впливу на реальні процеси [9].

Аналіз вітчизняних підприємств проведемо на прикладі ТОВ «Сільпо-ФУД», що є частиною однієї 3 найбільших рітейл груп країни Fozzy Group. Логістичні послуги для магазинів компанії надає власна логістика. Загалом, логістика компанії має у своєму складі 6 розподільчих центрів (РЦ), що розташовані у п'яти областях України, а саме: Запорізькій, Київській, Львівській, Одеській і Харківській. Дані розподільчі центри розміщені у всіх регіонах України, що дозволяє компанії застосовувати принцип 80/20 (80\% від товару у магазинах регіону, відвантажується із регіонального РЦ). Зазначений принцип дозволяє есрективно забезпечувати доступність товару на полицях магазинів мережі та знижує негативний вплив на екологію (відкриття львівського РЦ, дозволило знизити пробіг вантажівок компанії на 3,6 млн км, що сприятиме зниженню викидів $\mathrm{CO}_{2}$ у атмосфреру на 2208 тон за рік. Окрім відкриття нового РЦ, компанія відкрила доставку товарів 3 магазинів Сільпо, задля цього, у мобільному додатку компанії з'явився новий розділ, де покупці можуть замовляти продукцію, а створена служба доставки, доставляє цю продукцію. Впровадження доставки продукції з магазинів, дозволило компанії зберегти лояльність покупців, не втратити долю ринку та оптимізувати всі логістичні процеси [5].

Крім того, у 2021 році компанія реалізує пілотну версію інноваційного проекту доставки літаками. Такий тип транспортування запроваджується для забезпечення товарами покупців, що знаходяться в населених пунктах, де відсутні логістичні оператори. Для реалізації даного проєкту, компанією було переобладнано ангар для літаків у авіарозподільчий центр, у проект залучено 6 літаків. Тривалість доставки літаком обмежуються 40 хвилинами, це дозволяє забезпечити якість продукції [5].

Висновки. Отже, сучасна динаміка світової економіки зумовлює необхідність забезпечення гнучкості у діяльності підприємств, зокрема оптимізації логістичних процесів та впровадження інноваційних процесів у роботу логістичної системи. Пандемія COVID19 значно пришвидшила розвиток онлайн платорорм та сприяла значному зростанню їх частки на світовому ринку роздрібної торгівлі. Враховуючи, що діяльність більшості компаній тісно пов'язана з міжнародною діяльністю, ефективна логістична діяльність, $€$ одним 3 рушійних важелів розвитку, що забезпечує зростання конкурентоспроможності не лише в міжнародній торгівлі, а й в процесі реалізації продукції на вітчизняному ринку. Крім того, глобальні проблеми на ринку провоку-

Рейтинг вартості складський приміщень у світі, 2019-2020 рік

Таблиця 1

\begin{tabular}{|c|c|c|c|c|}
\hline $\begin{array}{l}\text { Місце у } \\
\text { рейтингу }\end{array}$ & Країна & Місто & $\begin{array}{c}\text { Ціна } \\
\text { (дол.м²/ рік) }\end{array}$ & $2020 / 2019(\%)$ \\
\hline 1 & Великобританія & Лондон & 7,59 & $13 \%$ \\
\hline 2 & Китай & Гонконг & 6,07 & $-10 \%$ \\
\hline 3 & США & Сан-Франциско & 5,56 & $0 \%$ \\
\hline 4 & Швейцарія & Женева & 5,48 & $0 \%$ \\
\hline 5 & Сінгапур & Сінгапур & 5,08 & $1 \%$ \\
\hline 159 & Україна & Київ & 1,69 & $0 \%$ \\
\hline 246 & Індія & Національний столичний регіон & 0,99 & $0 \%$ \\
\hline 247 & Туреччина & Анкара & 0,93 & $-15 \%$ \\
\hline 248 & Туреччина & Iзмір & 0,85 & $-17 \%$ \\
\hline 249 & Індія & Ахмадабад & 0,79 & $0 \%$ \\
\hline 250 & Індія & Гайдарабад & 0,74 & $3 \%$ \\
\hline
\end{tabular}


ють швидке створення інноваційних рішень які вирішують не лише поточні проблеми, а й забезпечують стабільність подальшого розвитку підприємств за рахунок ефективного використання інноваційних логістичних операцій та оптимізації логістичної діяльності.
Перспективами подальших досліджень є: підвищення рівня інвестиційної привабливості логістичної галузі, формування ефрективних механізмів застосування інноваційних логістичних процесів, що в свою чергу сприятимуть розвитку сучасних підприємств.

\section{СПИСОК ВИКОРИСТАНИХ ДЖЕРЕЛ:}

1. Гук О.В., Кучма О.Ю. Виклики логістичної галузі у період COVID-19. Сучасний стан економіки, обліку, фрінансів і права та їх основні проблеми : збірник тез доповідей міжнародної науково-практичної консреренції (Полтава, 5 жовтня 2021 р.) : у 2 ч. Полтава : ЦФЕНД, 2021. Ч. 2. C. 54. URL: http://www.economics.in.ua/ 2021/10/2.html

2. Coyote UPS Company. 2021 Logistics Trends: Top 7 Things Moving Supply Chain. URL: https://resources.coyote.com/source/logistics-trends

3. Гук О.В., Мельник А.В. Технологічний розвиток підприємства як складова його інноваційного розвитку. Сучасний стан економіки, обліку, фрінансів і права та їх основні проблеми : збірник тез доповідей міжнародної науково-практичної конференції (Полтава, 5 жовтня 2021 р.) : у 2 ч. Полтава : ЦФЕНД, 2021. Ч. 2. С. 29. URL: http://www.economics.in.ua/2021/10/2.html

4. The future of ecommerce. URL: https://www.shopify.com/enterprise/the-future-of-ecommerce/retail-industry (дата звернення: 18.10.2021).

5. Офіційний сайт «ТОВ «Сільпо-ФУД». URL: https://silpo.ua/

6. Global Logistics Outlook. D. Brown, L. Graham, J. Tollier. URL: https://www.cushmanwakefield.com/en/ insights/global-logistics-outlook

7. Commercial air transport in August 2021: in recovery. 14.09.2021. URL: https://ec.europa.eu/eurostat/web/ products-eurostat-news/-/ddn-20210914-1

8. Кустріч Л.О. Логістичні інновації як основа управління підприємством. Економіка та держава. 2020. № 2. C. 10-14. DOI: https://doi.org/10.32702/2306-6806.2020.2.10. URL: http://www.economy.in.ua/ ?op $=1 \& z=4503 \& \mathrm{i}=1$

9. Інновації в галузі логістики. 2020. URL: https://sfii.gov.ua/innovacii-v-galuzi-logistiki/

\section{REFERENCES:}

1. Guk O.V., Kuchma O.Yu. (2021) Vyklyky lohistychnoyi haluzi u period COVID-19 [Challenges of the logistics industry in the period of COVID-19]. Suchasnyy stan ekonomiky, obliku, finansiv i prava ta yikh osnovni problemy: zbirnyk tez dopovidey mizhnarodnoyi naukovo-praktychnoyi konferentsiyi (Poltava, 5 zhovtnya 2021 r.): u 2 ch. Poltava: TSFEND, ch. 2, p. 54. Available at: http://www.economics.in.ua/2021/10/2.html

2. Coyote UPS Company. 2021 Logistics Trends: Top 7 Things Moving Supply Chain. Available at: https://resources.coyote.com/source/logistics-trends

3. Guk O.V., Mel'nyk A.V. (2021) Tekhnolohichnyy rozvytok pidpryyemstva yak skladova yoho innovatsiynoho rozvytku [Technological development of the enterprise as a component of its innovative development]. Suchasnyy stan ekonomiky, obliku, finansiv i prava ta yikh osnovni problemy: zbirnyk tez dopovidey mizhnarodnoyi naukovo-praktychnoyi konferentsiyi (Poltava, 5 zhovtnya 2021 r.): u 2 ch. Poltava: TSFEND, ch. 2, p. 29. Available at: http://www.economics.in.ua/2021/10/2.html

4. The future of ecommerce. Available at: https://www.shopify.com/enterprise/the-future-of-ecommerce/retail-industry

5. Ofitsiynyy sayt «TOV «Sil'po-FUD» [Official site of Silpo-FOOD LLC]. Available at: https://silpo.ua/

6. Global Logistics Outlook. D. Brown, L. Graham, J. Tollier. Available at: https://www.cushmanwakefield.com/ en/insights/global-logistics-outlook

7. Commercial air transport in August 2021: in recovery. 14.09.2021. Available at: https://ec.europa.eu/eurostat/ web/products-eurostat-news/-/ddn-20210914-1

8. Kustrich L. (2020) Lohistychni innovatsiyi yak osnova upravlinnya pidpryyemstvom [Logistics innovations as the basis of enterprise management]. Ekonomika ta derzhava - Economy and state, 2, 10-14. DOI: https://doi.org/ 10.32702/2306-6806.2020.2.10. Available at: $\mathrm{http}: / / \mathrm{www}$.economy.in.ua/?op=1\&z=4503\&i=1

9. Innovacii v galuzi logistiki [Innovations in the field of logistics]. Available at: https://sfii.gov.ua/innovacii-vgaluzi-logistiki/ 